\title{
CROP ROTATION AFFECTS POPULATIONS OF SOILBORNE PATHOGENS IN POTATO SOIL
}

\author{
A.T. MARSH and L-H. CHEAH \\ Crop \& Food Research, Private Bag 11600, Palmerston North, New Zealand \\ Corresponding author: cheahl@crop.cri.nz
}

\begin{abstract}
Soilborne diseases (caused by Phytophthora and Pythium spp.) are limiting factors for potato growers in the Manawatu region of New Zealand. A long-term trial (5 years) is being conducted at a commercial property on land that has a history of severe infestation by soilborne diseases. Five rotational crops (potato, pasture, brassica, cereal and squash) are being tested for their ability to reduce the inoculum of the soilborne pathogens. Metalaxyl fungicide is used as a standard treatment. Soil samples were taken before and after each crop rotation treatment and plated on agar media to study the pathogen populations. In the second year (2005-06), results showed that there was a significant reduction in Phytophthora spp. inoculum in the soil compared with the first year (200405) after rotation with pasture and BQ Mulch (brassica biofumigant). The population of Pythium spp. was reduced with BQ Mulch and cereal, which also reduced the total population of other (unknown) fungi. Fusarium had infested some plots but there were no differences in Fusarium populations between the treatments. BQ Mulch is a brassica line that was bred and selected to contain high levels of glucosinolates. These results indicate that the toxic vapour (isothiocyanates) released by the crushed BQ Mulch tissues may have killed the soilborne pathogens.
\end{abstract}

\section{SYNCHYTRIUM ENDOBIOTICUM (POTATO WART) ERADICATION FROM NEW ZEALAND}

\author{
H.G. PEARSON ${ }^{1}$, M. BRAITHWAITE ${ }^{2}$ and I. VELJKOVIC ${ }^{3}$ \\ ${ }^{1}$ Biosecurity New Zealand, PO Box 2095, Auckland, New Zealand \\ ${ }^{2}$ Biosecurity New Zealand, PO Box 24, Lincoln, New Zealand \\ ${ }^{3}$ Biosecurity New Zealand, PO Box 2526, Wellington, New Zealand
}

Corresponding author: heather.pearson@maf.govt.nz

Synchytrium endobioticum causes the disease potato black wart in Solanum tuberosum (potato). This disease is under mandatory phytosanitary control in many countries world-wide. It is reported as eradicated from New Zealand. Isolated incidences of potato wart have occurred occasionally in home gardens in the southern regions of the South Island. Each time this disease has been detected official movement control measures have been implemented. Organism management includes fumigation of the affected soil using methyl bromide at a rate of $380 \mathrm{~g} / \mathrm{m}^{2}$ for 24 hours. In each case an investigation is initiated to detect the origin of the inoculum. The treated ground is replanted with potato varieties susceptible to $S$. endobioticum as an indicator of whether the pathogen is still present in the soil. A public awareness programme disseminates information throughout the growing season in areas that have previously experienced potato wart. 